\title{
INTERACTIONS BETWEEN ADJUVANTS AND THE FUNGICIDE AZOXYSTROBIN+BENZOVINDIFLUPYR IN HYDRAULIC SPRAYING
}

\author{
Thiago N. Landim¹, João P. A. R. da Cunha ${ }^{2 *}$, Guilherme S. Alves ${ }^{3}$, Matheus G. Marques², \\ Sérgio M. Silva ${ }^{4}$
}

${ }^{2 *}$ Corresponding author. Universidade Federal de Uberlândia/ Uberlândia - MG, Brasil.

E-mail: jpcunha@ufu.br| ORCID ID: http://orcid.org/0000-0001-8872-3366

KEYWORDS
spray solution
additives, droplet
spectrum, surfactants,
application
technology.

\begin{abstract}
Adjuvants are tools to maximize pesticide spray quality. This study aimed to evaluate the interaction effects between adjuvants and the fungicide azoxystrobin + benzovindiflupyr on the physicochemical characteristics, droplet evaporation time, and spray droplet size. The experiment was carried out using a $2 \times 6$ factorial scheme, in which the first factor was the absence or presence of the fungicide mixture (water or water + fungicide) and the second factor was the presence of different adjuvants (water and five adjuvants). The parameters evaluated were surface tension, $\mathrm{pH}$, viscosity, electrical conductivity, droplet evaporation time, volume median diameter, percentage of droplets smaller than $100 \mu \mathrm{m}$, and relative amplitude of the droplet spectrum. The silicone and propionic acid + soy lecithin adjuvants reduced the $\mathrm{pH}$ of the spray solution, and the sodium lauryl ether sulfate, propionic acid + soy lecithin, and orange essential oil adjuvants reduced droplet evaporation when mixed with the fungicide. All tested adjuvants improved spray quality related to the characteristics of the droplet spectrum, reducing the percentage of droplets smaller than $100 \mu \mathrm{m}$, and allowing more uniform droplet size. The fungicide azoxystrobin + benzovindiflupyr affected droplet evaporation time.
\end{abstract}

\section{INTRODUCTION}

The process of droplet formation in hydraulic spraying is complex and largely dependent on the physicochemical properties of the spray solution. Nonetheless, the use of adjuvants can change these properties and affect application performance (Totoli et al., 2016; Cunha et al., 2010).

Adjuvants are substances added to spray solutions and directly or indirectly may improve spraying applications, increase the efficiency of pesticides and reduce application risks, and decrease the impact of pesticides on the environment and operators (Costa et al., 2014; Madureira et al., 2015). Adjuvants are divided into two groups: activating adjuvants (mineral oil, vegetable oil, and nitrogen fertilizers), which directly improve crop protection by allowing higher product absorption by the plant cuticle; modifiers of the surface tension of liquids (adherents, dispersants, surfactants, and spreaders).
Adjuvants can also change the $\mathrm{pH}$ of spray solutions, droplet evaporation time, drift-prone droplet formation, and the formation of foam in the spray solution (Queiroz et al., 2008). However, adjuvants should be chosen carefully because of the large number of products commercially available and high variability in the mode of action. Adjuvants added to spray solutions can also interact with pesticides; these interactions are variable and may reduce application performance.

Cunha et al. (2017) have shown that the effect of adjuvants on the physicochemical characteristics of spray solutions depends on the adjuvant's chemical composition and interaction with crop protection products, although in many situations, they significantly increase the effectiveness of treatment (Ryckaert et al., 2007). In this context, azoxystrobin and benzovindiflupyr is a fungicide mixture commonly used for disease management in various crops, including soybean (Ribeiro et al., 2017; Godoy et al., 2016).

\footnotetext{
${ }^{1}$ Syngenta Seeds/ Formosa - GO, Brasil.

${ }^{2}$ Universidade Federal de Uberlândia/ Uberlândia - MG, Brasil.

${ }^{3}$ University of Nebraska-Lincoln/ North Platte - NE, EUA.

${ }^{4}$ Universidade Federal dos Vales do Jequitinhonha e Mucuri/ Unaí - MG, Brasil.

Received in: 7-19-2018

Accepted in: 6-24-2019
} 
This study aimed to evaluate the effects of the interaction between adjuvants and the fungicide azoxystrobin + benzovindiflupyr on the physicochemical characteristics, droplet evaporation time, and spray droplet size.

\section{MATERIAL AND METHODS}

The evaporation parameters and physicochemical properties of droplets were analyzed at the Agricultural Mechanization Laboratory at the Federal University of Uberlândia, located in Uberlândia, state of Minas Gerais, Brazil. Droplet size was analyzed at the Agroforestry
Machinery and Tire Testing Center of the Paulista State University "Júlio de Mesquita Filho" in Botucatu campus, located in Botucatu, state of São Paulo, Brazil.

The experiments were carried out using a completely randomized block design with a $2 \times 6$ factorial scheme and four replications. The evaluated factors were the presence or absence of the fungicide mixture (azoxystrobin $300 \mathrm{~g} \mathrm{~kg}^{-}$ ${ }^{1}+$ benzovindiflupyr $150 \mathrm{~g} \mathrm{~kg}^{-1}$ at rate of $200 \mathrm{~g} \mathrm{ha}^{-1}$ ) and the presence of different adjuvants (five adjuvants and distilled water) (Table 1). All rates/concentrations of the products were calculated following the manufacturers' recommendation considering a spraying rate of $77 \mathrm{~L} \mathrm{ha}^{-1}$.

TABLE 1. Treatments used to evaluate physicochemical characteristics, droplet evaporation time, and spray droplet size. Uberlândia, Minas Gerais, Brazil, 2017.

\begin{tabular}{|c|c|c|c|}
\hline Treatments & Adjuvants & Rate & Fungicide \\
\hline $\mathrm{T} 1$ & Multifunctional organic molecules based (OA) & $40 \mathrm{~mL} \mathrm{ha}^{-1}$ & \\
\hline $\mathrm{T} 2$ & Sodium lauryl ether sulfate (SLES) & $50 \mathrm{~mL} 100 \mathrm{~L}^{-1}$ & \\
\hline $\mathrm{T} 3$ & Propionic acid + soy lecithin (PASL) & $500 \mathrm{~mL} 100 \mathrm{~L}^{-1}$ & Present \\
\hline $\mathrm{T} 4$ & Orange essential oil (OEO) & $100 \mathrm{~mL} \mathrm{ha}^{-1}$ & \\
\hline $\mathrm{T} 5$ & Multifunctional silicone based (SA) & $100 \mathrm{~mL} \mathrm{ha}^{-1}$ & \\
\hline T6 & Water & - & \\
\hline $\mathrm{T} 7$ & Multifunctional organic molecules based (OA) & $40 \mathrm{~mL} \mathrm{ha}^{-1}$ & \\
\hline $\mathrm{T} 8$ & Sodium lauryl ether sulfate (SLES) & $50 \mathrm{~mL} 100 \mathrm{~L}^{-1}$ & \\
\hline T9 & Propionic acid + soy lecithin (PASL) & $500 \mathrm{~mL} 100 \mathrm{~L}^{-1}$ & Absent \\
\hline $\mathrm{T} 10$ & Orange essential oil (OEO) & $100 \mathrm{~mL} \mathrm{ha}^{-1}$ & \\
\hline $\mathrm{T} 11$ & Multifunctional silicone based (SA) & $100 \mathrm{~mL} \mathrm{ha}^{-1}$ & \\
\hline $\mathrm{T} 12$ & Water & - & \\
\hline
\end{tabular}

The OA adjuvant is recommended to improve foliar penetration and serve as a surfactant, anti-foam, and anti-drift agent. The SLES adjuvant is a synthetic adjuvant containing surfactants, sequestrants, and emulsifiers, with antievaporation and adhesive-spreading properties. The PASL adjuvant is recommended to reduce surface tension and drift, maintain droplet size uniformity, and improve the buffer capacity of spray solutions. The OEO adjuvant is recommended to reduce surface tension and increase adhesion and reduce spray drift. The SA adjuvant is recommended to reduce the $\mathrm{pH}$ of the solution and spray drift.

\section{Physicochemical properties}

The physicochemical properties evaluated were surface tension, $\mathrm{pH}$, viscosity, and electrical conductivity (EC). The $\mathrm{pH}$ and EC were measured directly in the solutions using a portable $\mathrm{pH}$ and conductivity meter (Hanna, HI98139). Dynamic viscosity was determined using a rotational viscometer microprocessor model Q860M21 (Quimis, São Paulo, SP, Brazil), using the rotor no. 0 at $60 \mathrm{rpm}$. This direct measuring viscometer operates on the principle of the rotation of a cylinder (measuring head) submerged in the sample by measuring the torsional force required to overcome rotational resistance.

Surface tension was determined using a bench tensiometer with a platinum ring (Kruss, K6) and the Du Nouy method (Dopierala \& Prochaska, 2008). The tensiometer was calibrated with distilled water. The test consisted of measuring the tension of the ring located at the end of a flexible rod placed on the surface of the sample, which was pulled until the liquid film ruptured. The test was performed according to the methodology of Cunha et al. (2010).

\section{Analysis of droplet evaporation time}

Droplet evaporation time was assessed by a method adapted from Corrêa \& Maziero (1980), who used fiberglass to maintain droplets spherical and determine evaporation time.

The $17 \mu \mathrm{m}$-diameter fiberglass strands were obtained by shredding a fiberglass sheet. The strands were mounted on a $3 \times 3 \mathrm{~cm}$ wooden frame. A hand sprayer was used at a distance of $0.3 \mathrm{~m}$ to create droplets on the strands. After spraying, the strands were immediately transferred to a USB digital microscope, where droplets with a size close to $300 \mu \mathrm{m}$ were selected using DinoCapture software version 2.0. Immediately after selecting droplet size, a timer was set, and after $1 \mathrm{~min}$, an image of each droplet was acquired, and its diameter was measured. Data on droplet diameter were obtained directly by calibrating the DinoCapture software version 2.0 using a reticle. Without changing the microscope focus, a circle corresponding to the margin of the droplet was drawn, allowing obtaining droplet diameter. The percentage of reduction in droplet size was determined by the difference in diameter between times 0 and $1 \mathrm{~min}$.

Droplet evaporation time was analyzed inside a biosafety cabinet to minimize climatic variations in the laboratory. The analyses were performed at $26 \pm 2{ }^{\circ} \mathrm{C}$ and relative humidity of $30 \pm 3 \%$, which was chosen to allow greater differentiation between treatments. 


\section{Droplet spectrum}

Droplet size was evaluated directly using a realtime analyzer equipment (VisiSizer P15 $5^{\circledR}$, Oxford Lasers, Imaging Division, Oxford, England). To obtain average values, the equipment counted ten thousand droplets in each replication.

The instrument was calibrated using a standard TeeJet nozzle model XR 11002. After calibration, a pressurized $\mathrm{CO}_{2}$ sprayer was used to spray the solution transversely to the light beam. The flat nozzle tip used was AD 11002 (MagnoJet), which was fixed $0.5 \mathrm{~m}$ above the optical beam. The working pressure was 3 bar $(300 \mathrm{kPa})$.

A $10-\mathrm{L}$ container was used to prepare the solution, and the container was washed between each treatment to remove residues and clean the sprayer system.

The tests were carried out in a controlled environment to maintain the environmental conditions constant (air temperature below $26^{\circ} \mathrm{C}$, relative air humidity above $60 \%$, and no wind).

The parameters evaluated were: Dv0.5 (also known as the volume median diameter [VMD]) (droplet diameter such that $50 \%$ of the spray volume contained droplets smaller than this value), percent of spray volume contained in droplets less than $100 \mu \mathrm{m}(\%<100 \mu \mathrm{m})$, and the relative span (SPAN index).

\section{Statistical analysis}

All data were subjected to assumption tests at $1 \%$ significance. The Levene's test was used to assess homogeneity of variance, and the Shapiro-Wilk's test was used to verify normality of residual. After confirming the assumptions, the data were subjected to analysis of variance using SISVAR software version 5.3. Treatment averages were compared using the Scott-Knott's test at 5\% significance.

\section{RESULTS AND DISCUSSION}

The mean $\mathrm{pH}$ and EC values are shown in Table 2. The results showed a significant interaction effect between adjuvants and fungicide. Changes in $\mathrm{pH}$ and $\mathrm{EC}$ were observed in all treatments. In the absence of the fungicide mixture, the SA adjuvant had the lowest $\mathrm{pH}$ (3.22) whereas the SLES adjuvant had the highest $\mathrm{pH}(8.17)$. In the presence of fungicide, the lowest and highest $\mathrm{pH}$ of the spray solution was obtained using PASL (5.22) and water (10.65), respectively. The decrease in $\mathrm{pH}$ by the silicone adjuvant and propionic acid + soy lecithin relative to water can be due to the presence of acids in the composition.

The SA and AO adjuvants produced the highest EC in the absence of the fungicide, increasing the EC in up to $20 \%$ compared to water. In the presence of the fungicide, the highest and lowest EC were produced using the SA and OEA adjuvants (1172 and $256 \mu \mathrm{S} \mathrm{cm}^{-1}$ ).

The analysis of data from $\mathrm{pH}$ and $\mathrm{EC}$ indicated that the fungicide mixture increased solution $\mathrm{pH}$ and $\mathrm{EC}$ compared with the solution without adjuvants and regardless of the adjuvant type used.

The EC depends on the presence of ions such as $\mathrm{Ca}^{+2}$, $\mathrm{Fe}^{+2}$, and $\mathrm{Al}^{+3}$. However, these ions may react with other substances in the spray solution, including active ingredients, and potentially decrease the efficacy of pesticides. Another factor influencing pesticide effectiveness is $\mathrm{pH}$ since each product has an optimal $\mathrm{pH}$ range. If a spray solution has a $\mathrm{pH}$ out of its optimal range, half-life of its molecule may be affected (Carlson \& Burnside, 1984).

Cunha et al. (2017) found that the interaction between adjuvants and fungicides affected the physicochemical characteristics of spray solutions, including $\mathrm{pH}$ and EC. Moreover, the effect was dependent on the types of adjuvants and fungicides used. Therefore, the results found in their study and our study cannot be generalized to other products.

TABLE 2. Hydrogen potential and electrical conductivity of spray solutions with adjuvants in the presence or absence of fungicide. Uberlândia, Minas Gerais, Brazil, 2017.

\begin{tabular}{|c|c|c|c|c|c|c|c|}
\hline \multirow{3}{*}{ Adjuvants } & \multicolumn{3}{|c|}{$\mathrm{pH}$} & \multicolumn{4}{|c|}{$\begin{array}{c}\text { Electrical conductivity } \\
\left(\mu \mathrm{S} \mathrm{cm}^{-1}\right)\end{array}$} \\
\hline & \multicolumn{3}{|c|}{ Fungicide } & \multicolumn{4}{|c|}{ Fungicide } \\
\hline & \multicolumn{2}{|c|}{ Presence } & Absence & \multicolumn{2}{|c|}{ Presence } & \multicolumn{2}{|c|}{ Absence } \\
\hline $\mathrm{OA}$ & 8.42 & $\mathrm{Da}$ & $7.79 \mathrm{Cb}$ & 504 & $\mathrm{Ca}$ & 405 & $\mathrm{Ab}$ \\
\hline SLES & 10.11 & $\mathrm{Ba}$ & $8.17 \mathrm{Ab}$ & 346 & $\mathrm{Ea}$ & 53 & $\mathrm{Db}$ \\
\hline PASL & 5.22 & $\mathrm{Fa}$ & $4.04 \mathrm{~Eb}$ & 870 & $\mathrm{Ba}$ & 207 & $\mathrm{Cb}$ \\
\hline OEO & 9.34 & $\mathrm{Ca}$ & $8.01 \mathrm{Bb}$ & 256 & $\mathrm{Fa}$ & 12 & $\mathrm{~Eb}$ \\
\hline SA & 6.39 & $\mathrm{Ea}$ & $3.22 \mathrm{Fb}$ & 1172 & $\mathrm{Aa}$ & 276 & $\mathrm{Bb}$ \\
\hline Water & 10.65 & $\mathrm{Aa}$ & $6.48 \mathrm{Db}$ & 458 & $\mathrm{Da}$ & 2 & $\mathrm{Fb}$ \\
\hline $\mathrm{CV}(\%)$ & \multicolumn{3}{|c|}{0.32} & \multicolumn{4}{|c|}{0.15} \\
\hline $\mathrm{F}_{\mathrm{adj}}$ & \multicolumn{3}{|c|}{$45,363.32^{*}$} & \multicolumn{4}{|c|}{$38,6493.90^{*}$} \\
\hline$F_{\text {fung }}$ & \multicolumn{3}{|c|}{$69,726.76^{*}$} & \multicolumn{4}{|c|}{$2,416,220.53^{*}$} \\
\hline$F_{\text {adj } x \text { fung }}$ & \multicolumn{3}{|c|}{$4,903.76^{*}$} & \multicolumn{4}{|c|}{$77,121.53^{*}$} \\
\hline
\end{tabular}

Means followed by different letters (upper case in columns and lower case in rows) were significantly different from each other using the ScottKnott's test at $5 \%$ significance. CV (\%), coefficient of variation; $\mathrm{F}_{\text {adj }}, \mathrm{F}$-value for adjuvants; $\mathrm{F}_{\text {fung, }}$ F-value for fungicide; $\mathrm{F}_{\text {adj }} \mathrm{x}$ fung, $\mathrm{F}$-value for adjuvants $\times$ fungicide; *significant at $0.05 ;{ }^{\text {ns }}$ not significant; OA, organic molecule-based adjuvant; SLES: sodium lauryl ether sulfate; PASL, propionic acid + soy lecithin; OEO, orange essential oil; SA, silicone adjuvant.

The analysis of the viscosity and surface tension of the spray solutions is presented in Table 3 . There was an interaction effect between the factors adjuvants and fungicide. Except for PASL, the other adjuvants reduced the viscosity, especially the OA adjuvant, which strongly decreased viscosity in the absence of the fungicide mixture. In the presence of fungicide, OA, OEO, and SA adjuvants, as well as the fungicide mixture alone, reduced solution viscosity. The effect of adjuvants on spray solutions is complex and variable and these results evidenced this 
complexity. The presence of the fungicide mixture reduced the viscosity of the spray solution. However, the fungicide combined with the OA or SLES increased the viscosity.

All adjuvants, including the fungicide mixture alone, decreased surface tension, with values ranging from 54.5 and $28 \mathrm{mN} \mathrm{m}^{-1}$. The lowest values were found in the absence of fungicide, corresponding to 28.0 and $28.5 \mathrm{mN} \mathrm{m}^{-1}$ for SA and OA, respectively. The presence of fungicide increased surface tension, except for PASL adjuvant, which reduced surface tension relative to fungicide alone.

Studying spray solution viscosity is crucial because this variable can affect spray drift and droplet evaporation time. Stock \& Briggs (2000) observed that an increase in solution viscosity increased droplet size, consequently reducing spray drift and droplet evaporation.

The variations in spray solution viscosity were small, especially when the fungicide was added to the mixture, possibly due to the low concentrations of adjuvants recommended by manufacturers. Therefore, significant effects of viscosity on spraying performance may not be expected.

Surface tension is directly related to the ability of droplets to spread across the biological target, which may provide higher leaf coverage and wetting (Xu et al., 2010; Cunha et al., 2017). In contrast, excessive spreading may lead to solution run-off and shorter droplet life on the leaves, which may reduce the absorption of the active ingredient.

TABLE 3. Viscosity and surface tension of spray solutions with adjuvants in the presence or absence of fungicide. Uberlândia, Minas Gerais, Brazil, 2017.

\begin{tabular}{|c|c|c|c|c|c|c|c|c|}
\hline \multirow{3}{*}{ Adjuvants } & \multicolumn{4}{|c|}{ Viscosity (mPa s) } & \multicolumn{4}{|c|}{$\begin{array}{l}\text { Surface tension } \\
\quad\left(\mathrm{mN} \mathrm{m}^{-1}\right)\end{array}$} \\
\hline & \multicolumn{4}{|c|}{ Fungicide } & \multicolumn{4}{|c|}{ Fungicide } \\
\hline & \multicolumn{2}{|c|}{ Presence } & \multicolumn{2}{|c|}{ Absence } & \multicolumn{2}{|c|}{ Presence } & \multicolumn{2}{|c|}{ Absence } \\
\hline $\mathrm{OA}$ & 0.98 & $\mathrm{Ba}$ & 0.93 & $\mathrm{Cb}$ & 31.50 & $\mathrm{Db}$ & 28.50 & $\mathrm{Ea}$ \\
\hline SLES & 1.01 & $\mathrm{Aa}$ & 0.98 & $\mathrm{Bb}$ & 38.25 & $\mathrm{Bb}$ & 35.00 & $\mathrm{Ca}$ \\
\hline PASL & 1.01 & $\mathrm{Aa}$ & 1.00 & $\mathrm{Aa}$ & 33.00 & $\mathrm{Ca}$ & 35.75 & $\mathrm{Bb}$ \\
\hline $\mathrm{OEO}$ & 0.97 & $\mathrm{Ba}$ & 0.97 & $\mathrm{Ba}$ & 30.75 & $\mathrm{~Eb}$ & 30.00 & $\mathrm{Da}$ \\
\hline SA & 0.98 & $\mathrm{Ba}$ & 0.98 & $\mathrm{Ba}$ & 28.25 & $\mathrm{Fa}$ & 28.00 & $\mathrm{Ea}$ \\
\hline Water & 0.97 & $\mathrm{Bb}$ & 1.02 & $\mathrm{Aa}$ & 54.50 & $\mathrm{Aa}$ & 72.00 & $\mathrm{Ab}$ \\
\hline $\mathrm{CV}(\%)$ & \multicolumn{4}{|c|}{1.00} & \multicolumn{4}{|c|}{1.10} \\
\hline$F_{\text {adj }}$ & \multicolumn{4}{|c|}{$26.03^{*}$} & \multicolumn{4}{|c|}{$8,329.50^{*}$} \\
\hline$F_{\text {fung }}$ & \multicolumn{4}{|c|}{$6.24^{*}$} & \multicolumn{4}{|c|}{$338.00^{*}$} \\
\hline$F_{\text {adj } x \text { fung }}$ & \multicolumn{4}{|c|}{$25.61^{*}$} & \multicolumn{4}{|c|}{$734.00^{*}$} \\
\hline
\end{tabular}

Means followed by different letters (upper case in columns and lower case in rows) were significantly different from each other using the Scott-

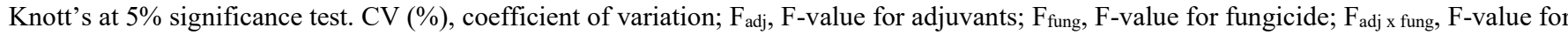
adjuvants $\times$ fungicide; *significant at 0.05 ; ${ }^{n}$ not significant; OA, organic molecule-based adjuvant; SLES: sodium lauryl ether sulfate; PASL, propionic acid + soy lecithin; OEO, orange essential oil; SA, silicone adjuvant.

The surface tension of spray solutions is decreased by surfactants present in many adjuvants and is reduced even further by surfactants in pesticide formulations. Cunha et al. (2017) evaluated the physicochemical properties of spray mixtures and found that there was a strong interaction effect between adjuvants and pesticides, supporting the results in this study.

Baio et al. (2015) and Sasaki et al. (2015) observed that adjuvants affected surface tension and spray viscosity, respectively. Surface tension ranged from 20.03 to 72.60 $\mathrm{mN} \mathrm{m}^{-1}$ and solution viscosity decreased up to $0.04 \%$, which corroborates the present study.

The analysis of droplet evaporation in the presence of adjuvants and fungicide is shown in Table 4. The results indicated a significant interaction effect between adjuvants and fungicide. The adjuvants affected droplet evaporation. Nonetheless, it depended upon the presence or absence of fungicide. In the absence of fungicide, SLES and OEO did not affect droplet diameter compared to water by itself. The other adjuvants caused the largest reduction in droplet diameter, especially the SA, which decreased the diameter by $10 \%$. In the presence of fungicide, OA and SA caused the most significant reduction in droplet diameter, corresponding to $10.69 \%$ and $12.10 \%$, respectively, which was similar to water. The SLES, PASL, and OEO adjuvants decreased droplet evaporation.

The fungicide mixture alone increased the reduction in droplet diameter from $4.38 \%$ to $9.04 \%$. Several studies have already evaluated the evaporation time of droplets on surfaces (Baio et al., 2015; Xu et al., 2010; Yu et al., 2009). This may help understand the evaporation process after droplets reach the target area since surface contact changes droplet shape and evaporation time (Erbil, 2015; Santiago, 2016). However, the evaporation time of surface droplets is different from that of airborne droplets; therefore, the results of these comparisons should be analyzed with caution. 
TABLE 4. Droplet evaporation expressed as a reduction in droplet diameter (\%) with adjuvants in the presence or absence of fungicide. Uberlândia, Minas Gerais, Brazil, 2017.

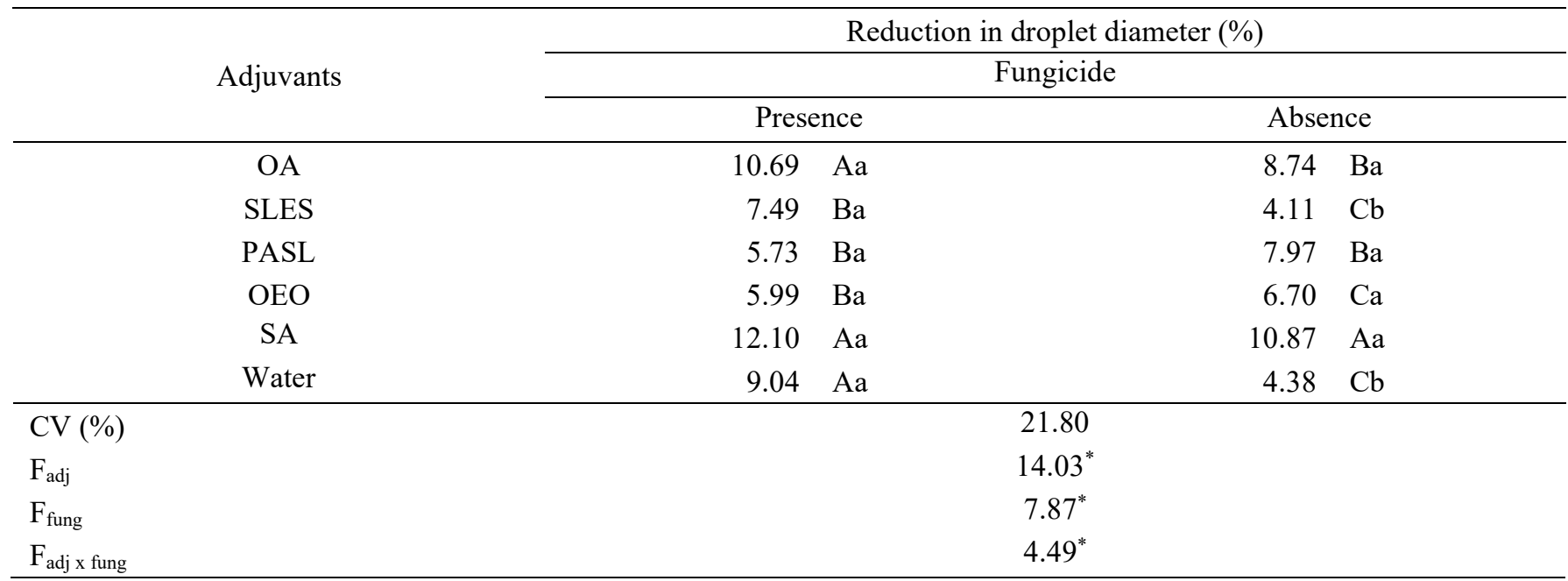

Means followed by different letters (upper case in columns and lower case in rows) were significantly different from each other using the Scott-

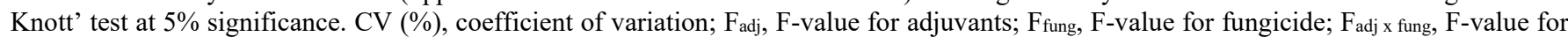
adjuvants $\times$ fungicide; *significant at 0.05 ; ${ }^{\text {ns }}$ not significant; OA, organic molecule-based adjuvant; SLES: sodium lauryl ether sulfate; PASL, propionic acid + soy lecithin; OEO, orange essential oil; SA, silicone adjuvant.

Some studies found that adjuvants might delay or accelerate droplet evaporation time. The type of adjuvant dictates the rate of evaporation, and silicone adjuvants can increase evaporation (Baio et al., 2015; Xu et al., 2010). However, the spray solutions used in these studies contained only adjuvants and water.

Vilela (2012) determined the effect of adjuvants in spray solutions containing the fungicide azoxystrobin + cyproconazole on surface droplet evaporation time and found a significant effect of a silicone adjuvant relative to other adjuvants. They also noted that the longest evaporation time was produced using vegetable oil.

The analysis of the SPAN index in the presence of adjuvants and in the presence or absence of fungicide is shown in Table 5. The results showed a significant interaction effect between adjuvants and fungicide.

TABLE 5. Relative span of droplet spectrum (SPAN index) of hydraulic spraying with adjuvants in the presence or absence of fungicide in the spray solution. Uberlândia, Minas Gerais, Brazil, 2017.

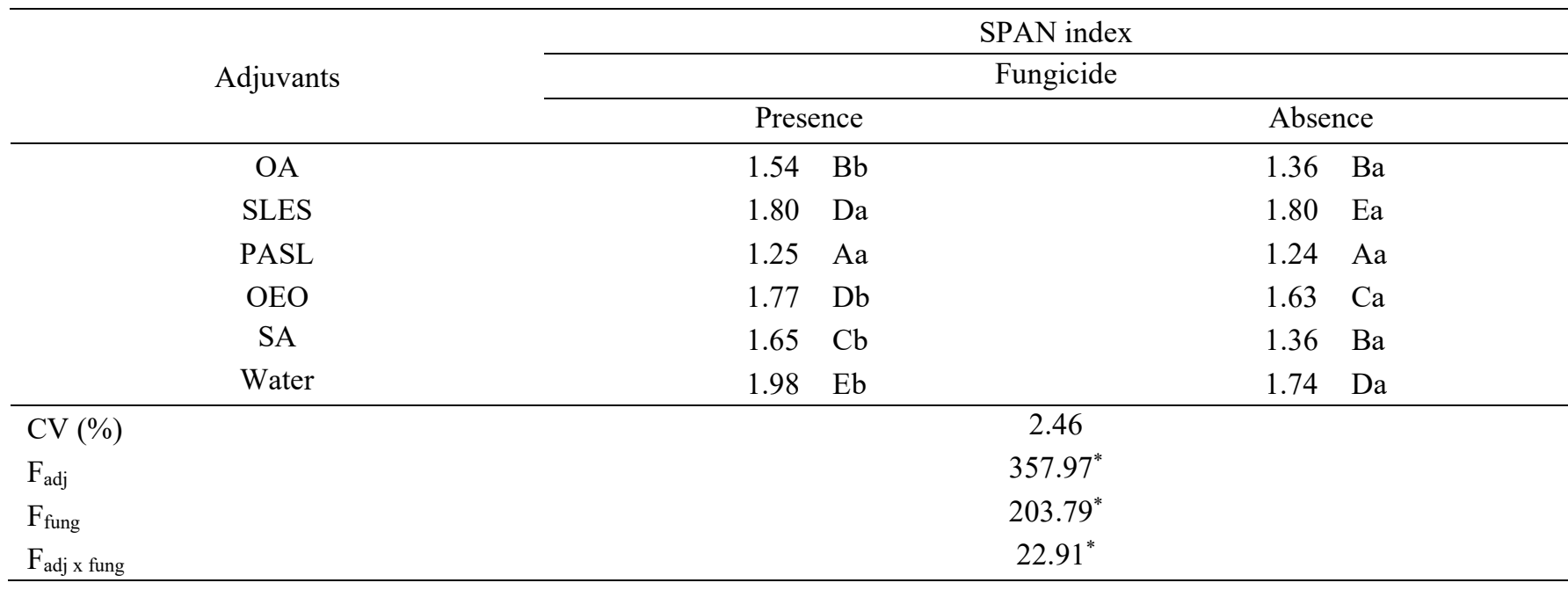

Means followed by different letters (upper case in columns and lower case in rows) were significantly different from each other using the ScottKnott's test at 5\% significance. CV (\%), coefficient of variation; $F_{\text {adj }}, \mathrm{F}$-value for adjuvants; $\mathrm{F}_{\text {fung, }}$ - F-value for fungicide; $\mathrm{F}_{\text {adj } x \text { fung, }}$-value for adjuvants $\times$ fungicide; *significant at 0.05 ; ${ }^{\text {ns }}$ not significant; OA, organic molecule-based adjuvant; SLES: sodium lauryl ether sulfate; PASL, propionic acid + soy lecithin; OEO, orange essential oil; SA, silicone adjuvant.

The presence of adjuvants reduced the SPAN index, and the index using PASL was 1.25 and 1.24 in the presence and absence of fungicide, respectively. In turn, fungicide increased the SPAN index, except for treatments containing SLES and PASL.

The SPAN index is strongly associated with the quality of spraying, i.e., droplet size uniformity. Treatments with a lower SPAN index have a smaller range in droplet size. Therefore, theoretically, sprays with a SPAN index of 0 represent a condition in which all formed droplets have the same diameter and volume.

Sasaki et al. (2015) evaluated the SPAN index in spray solutions with different adjuvants and found smalls variations in droplet size. Treatment with SLES adjuvant 
produced the lowest SPAN index, which does not agree with the present study. However, the authors used a pneumatic sprayer, whereas a hydraulic sprayer was used in this study, demonstrating that the activity of adjuvants could also be affected by the droplet formation process.

Data on the VMD and the percent of spray volume contained in droplets less than $100 \mu \mathrm{m}$ in the presence of adjuvants and fungicide are shown in Table 6. There was a significant interaction effect between adjuvants and fungicide. The presence of adjuvants increased droplet diameter in comparison to water. One possible explanation for the increase in the VMD is the reduction in the number of smaller droplets, especially those smaller than $100 \mu \mathrm{m}$.
The results indicated that VMD increased as the number of droplets smaller than $100 \mu \mathrm{m}$ decreased.

The droplet diameter used in spraying is closely linked to the effectiveness of pest control, and the diameter should be adequate to prevent spray drift (Yu et al., 2009; Nascimento et al., 2012).

Studies have shown that VMD tends to change in the presence of adjuvants (Mota \& Antuniassi, 2013). The action of adjuvants depends on the nozzle tip and spray system used (Cunha et al., 2010). Sasaki et al. (2015) used a pneumatic spray system and observed that the VMD decreased when using adjuvants. Therefore, results found in this study are valid only under similar conditions.

TABLE 6. Volume median diameter (VMD) and percent of spray volume contained in droplets less than $100 \mu \mathrm{m}$ with adjuvants in the presence or absence of fungicide in the spray solution. Uberlândia, Minas Gerais, Brazil, 2017.

\begin{tabular}{|c|c|c|c|c|c|c|c|c|}
\hline \multirow{3}{*}{ Adjuvants } & \multicolumn{4}{|c|}{$\mathrm{VMD}(\mu \mathrm{m})$} & \multicolumn{4}{|c|}{$\%<100 \mu \mathrm{m}$} \\
\hline & \multicolumn{4}{|c|}{ Fungicide } & \multicolumn{4}{|c|}{ Fungicide } \\
\hline & \multicolumn{2}{|c|}{ Presence } & \multicolumn{2}{|c|}{ Absence } & \multicolumn{2}{|c|}{ Presence } & \multicolumn{2}{|c|}{ Absence } \\
\hline $\mathrm{OA}$ & 215 & $\mathrm{Bb}$ & 239 & $\mathrm{Aa}$ & 8.14 & $\mathrm{Bb}$ & 6.62 & $\mathrm{Aa}$ \\
\hline SLES & 186 & $\mathrm{Ea}$ & 179 & $\mathrm{Cb}$ & 13.04 & $\mathrm{Ea}$ & 14.05 & $\mathrm{Cb}$ \\
\hline PASL & 245 & $\mathrm{Aa}$ & 235 & $\mathrm{Ab}$ & 6.47 & $\mathrm{Aa}$ & 6.45 & $\mathrm{Aa}$ \\
\hline OEO & 196 & $\mathrm{Db}$ & 202 & $\mathrm{Ba}$ & 11.64 & $\mathrm{Db}$ & 10.27 & $\mathrm{Ba}$ \\
\hline SA & 208 & $\mathrm{Cb}$ & 236 & $\mathrm{Aa}$ & 9.98 & $\mathrm{Cb}$ & 6.45 & $\mathrm{Aa}$ \\
\hline Water & 163 & $\mathrm{Fb}$ & 178 & $\mathrm{Ca}$ & 16.75 & $\mathrm{Fb}$ & 14.12 & $\mathrm{Ca}$ \\
\hline CV (\%) & \multicolumn{4}{|c|}{0.20} & \multicolumn{4}{|c|}{0.24} \\
\hline $\mathrm{F}_{\mathrm{adj}}$ & \multicolumn{4}{|c|}{$429.96^{*}$} & \multicolumn{4}{|c|}{$297.08^{*}$} \\
\hline$F_{\text {fung }}$ & \multicolumn{4}{|c|}{$81.18^{*}$} & \multicolumn{4}{|c|}{$62.14^{*}$} \\
\hline$F_{\text {adj } x \text { fung }}$ & \multicolumn{4}{|c|}{$34.60^{*}$} & \multicolumn{4}{|c|}{$15.74^{*}$} \\
\hline
\end{tabular}

Means followed by different letters (upper case in columns and lower case in rows) were significantly different from each other using the ScottKnott's test. CV (\%), coefficient of variation; $F_{\text {adj }}, \mathrm{F}$-value for adjuvants; $F_{\text {fung, }}$ F-value for fungicide; $F_{\text {adj }} \mathrm{x}$ fung, F-value for adjuvants $\times$ fungicide; *significant at 0.05 ; ${ }^{n}$ not significant; OA, organic molecule-based adjuvant; SLES: sodium lauryl ether sulfate; PASL, propionic acid + soy lecithin; OEO, orange essential oil; SA, silicone adjuvant.

\section{CONCLUSIONS}

The silicone and propionic acid + soy lecithin adjuvants promoted greater $\mathrm{pH}$ reduction in solutions with or without the fungicide in mixture.

Adjuvants containing sodium lauryl ether sulfate, propionic acid + soy lecithin, and orange essential oil reduced spray droplet evaporation in the presence of the fungicide in the solution.

All analyzed adjuvants improved spray quality, reducing the number of droplets smaller than $100 \mu \mathrm{m}$, and increasing droplet size uniformity.

The fungicide azoxystrobin + benzovindiflupyr affected droplet evaporation time.

\section{ACKNOWLEDGEMENTS}

The authors would like to thank FAPEMIG (Research Foundation of the State of Minas Gerais), CNPq (National Council of Scientific and Technological Development) and CAPES (Coordination for the Improvement of Higher Education Personnel) for the financial support.

\section{REFERENCES}

Baio FHR, Gabriel RRF, Camolese HS (2015) Alteração das propriedades físico-químicas na aplicação contendo adjuvantes. Brazilian Journal of Biosystems Engineering 9(2):151-161. DOI:

http://dx.doi.org/10.18011/bioeng2015v9n2p151-161

Carlson KL, Burnside OC (1984) Comparative

phytotoxicity of glyphosate, SC-0224, SC-0545, and HOE00661. Weed Science 32(6):841-844. DOI:

https://doi.org/10.1017/S0043174500060094

Corrêa HG, Maziero JVG (1980) Análise em laboratório da redução da evaporação de gotículas para pulverizações agrícolas. Bragantia 39(10):79-87. DOI:

http://dx.doi.org/10.1590/S0006-87051980000100010

Costa AGF, Velini ED, Rossi CVS, Corrêa MR, Negrisoli E, Fiorini MV, Siono LM (2014) Adjuvantes na deriva de 2,4-D + glyphosateem condições de campo. Ciência Rural 44(3):387-392. DOI: http://dx.doi.org/10.1590/S010384782014000300001 
Cunha JPAR, Alves GS, Marques RS (2017) Tensão superficial, potencial hidrogeniônico e condutividade elétrica de caldas de produtos fitossanitários e adjuvantes. Revista Ciência Agronômica 48(2):261-270. DOI: http://dx.doi.org/10.5935/1806-6690.20170030.

Cunha JPAR, Bueno MR, Ferreira MC (2010) Espectro de gotas de pulverização com adjuvantes de uso agrícola. Planta Daninha 28:1153-1158. DOI: http://dx.doi.org/10.1590/S0100-83582010000500023

Dopierala K, Prochaska K (2008) The effect of molecular structure on the surface properties of selected quaternary ammonium salts. Journal of Colloid and Interface Science 321(1):220-226. DOI:

http://dx.doi.org/10.1016/j.jcis.2008.01.049

Erbil HY (2015) Control of stain geometry by drop evaporation of surfactant containing dispersions. Advances in Colloid and Interface Science 222:275-290. DOI: http://dx.doi.org/10.1016/j.cis.2014.08.004

Godoy CV, Seixas CDS, Soares RM, MarcelinoGuimarães FC, Meyer MC, Costamilan LM (2016) Asian soybean rust in Brazil: past, present, and future. Pesquisa Agropecuária Brasileira 51(5):407-421. DOI: http://dx.doi.org/10.1590/S0100-204X2016000500002

Madureira RP, Raetano CG, Cavalieri JD (2015) Interação pontas-adjuvantes na estimativa do risco potencial de deriva de pulverização. Revista Brasileira de Engenharia Agrícola e Ambiental 19(2):180-185. DOI: http://dx.doi.org/10.1590/18071929/agriambi.v19n2p180-185.

Mota AAB, Antuniassi UR (2013) Influência de adjuvantes no espectro de gotas de ponta com indução de ar. Energia na Agricultura 28(1):1-5. DOI: http://dx.doi.org/10.17224/EnergAgric.2013v28n1p01-05

Nascimento AB, Oliveira GM, Balan MG, Higashibara LR, Abi Saab OJG (2012) Deposição de glifosato e utilização de adjuvante para diferentes pontas de pulverização e horário de aplicação. Revista Brasileira de Tecnologia Aplicada nas Ciências Agrárias 5(2):105-116. DOI: http://dx.doi.org/10.5777/paet.v5i2.1672

Queiroz AA, Martins JAS, Cunha JPAR (2008) Adjuvantes e qualidade da água na aplicação de agrotóxicos. Bioscience Journal 24(4):8-19.
Ribeiro FC, Colombo GA, Carvalho EV, Pelúzio JM, Erasmo EAL (2017) Controle químico da mancha-alvo da soja (Corynespora casiicola) no cerrado tocantinenseBrasil. Journal Bioengineering, Food Science 4(1):26-36. DOI: http://dx.doi.org/10.18067/jbfs.v4i1.118

Ryckaert B, Spanoghe P, Haesaert G, Heremans B, Isebaert S, Steurbaut W (2007) Quantitative determination of the influence of adjuvants on foliar fungicide residues. Crop Protection 26(10):1589-1594. DOI: http://dx.doi.org/10.1016/j.cropro.2007.02.011

Santiago H (2016) Simulação de perdas por evaporação na pulverização aérea. Tese Doutorado em Engenharia Agrícola, Viçosa, Universidade Federal de Viçosa.

Sasaki RS, Teixeira MM, Santiago H, Madureira RP, Maciel CFS, Fernandes HC (2015) Adjuvantes nas propriedades físicas da calda, espectro e eficiência de eletrificação das gotas utilizando a pulverização eletrostática. Ciência Rural 45(2):2-7. DOI: http://dx.doi.org/10.1590/0103-8478cr20131604

Stock D, Briggs G (2000) Physicochemical properties of adjuvants: values and applications. Weed Technology 14(4):798-806.

Totoli DS, Soares JPC, Alberton O (2016) Eficiência do grupo químico das carboxamida + estrobilurina no controle da ferrugem asiática em diferentes estádios da soja. Arquivos de Ciência Veterinárias e Zoologia da UNIPAR 19(3):153-157. DOI: http://dx.doi.org/10.25110/arqvet.v19i3.2016.6088

Vilela CM (2012) Evaporação de gotas de caldas contendo fungicidas e adjuvantes depositadas em superfície. Dissertação Mestrado em Agronomia, Botucatu, Universidade Estadual Paulista, Faculdade de Ciências Agronômicas.

Xu L, Zhu H, Ozkan HE, Bagley B (2010) Adjuvant effects on evaporation time and wetted area of droplets on waxy leaves. Transactions of the Asabe 53(1):13-20. DOI: http://dx.doi.org/10.13031/2013.29495

Yu Y, Zhu H, Ozkan HE, Derksen R, Krause CR (2009) Evaporation and deposition coverage area of droplets containing insecticides and sprays additives on hydrophilic, hydrophobic, and crabapple leaf surfaces. Transactions of the Asabe 52(1):39-49. DOI: http://dx.doi.org/10.13031/2013.25939 